\title{
Removal of Radioactivity from Sediment Mud and Soil and Use for Cultivation of Safe Vegetables in Fukushima, and Removal of Toxic Metals Using Photosynthetic Bacteria
}

\author{
Kei Sasaki', Kaoru Nakamura1, Kenji Takeno', Hidenori Shinkawa', Nachiketa Das², \\ Ken Sasaki ${ }^{*}$ \\ ${ }^{1}$ Faculty of Engineering, Department of Food and Agriculture Bio-Recycle, Hiroshima Kokusai Gakuin University, \\ Hiroshima, Japan \\ ${ }^{2}$ Department of Geology, School of Earth Sciences, Ravenshaw University, Odisha, India \\ Email: ${ }^{*}$ sasaki259@live.jp
}

Received 10 July 2015; accepted 17 August 2015; published 20 August 2015

Copyright $(2015$ by authors and Scientific Research Publishing Inc.

This work is licensed under the Creative Commons Attribution International License (CC BY).

http://creativecommons.org/licenses/by/4.0/

c) (i) Open Access

\begin{abstract}
The immobilized photosynthetic bacterium, Rhodobacter shpaeroides SSI (SSI), cultured on porous $2 \mathrm{~cm}$ ceramic beads, effectively removed and recovered $20 \mathrm{mg} / \mathrm{L}$ of non-radioactive Cs (almost $100 \%)$ and $\mathrm{Sr}(\cong 50 \%)$, after 3 - 5 days of aerobic treatment. Toxic and heavy metals such as $\mathrm{Hg}, \mathrm{Cr}$, $\mathrm{Pb}$ and As were also removed, almost $100 \%$, after 6 days of aerobic treatment. A practical method of removal of radioactivity of $10-30 \mu \mathrm{Sv} / \mathrm{h}$, caused mainly by radioactive Cs released from the accident at the Daiichi Nuclear Power Plant on 11th March 2011, from sediment mud and soil in Fukushima, Japan, was also carried out. Using immobilized SSI beads, more than $90 \%$ and $42 \%-73 \%$ of radioactive Cs was removed and recovered from sediment mud and soil, respectively, after 3 14 days of aerobic treatment in an outdoor $60 \mathrm{~L}$ vessel. The weight and mass of the harvested beads could be reduced by more than $97 \%$ after desiccation. This technology of removal and recovery had therefore, considerable advantages over other technologies that demanded very large storage facilities in Fukushima. After removal of radioactivity from polluted soil, vegetables like Komatsuna (Turrip leaves) and Chingensai (Green pakchoi) were cultivated on remediated soil. Safe vegetables grown on these treated soils showed a radioactivity content lower than the recommended limit for edible foods in Japan, i.e. less than $<100 \mathrm{~Bq} / \mathrm{kg}$. Treatment by SSI beads, therefore, appeared to be a compact and suitable technology that could make significant contributions towards agricultural recovery in radioactively polluted areas of Fukushima.
\end{abstract}

"Corresponding author.

How to cite this paper: Sasaki, K., et al. (2015) Removal of Radioactivity from Sediment Mud and Soil and Use for Cultivation of Safe Vegetables in Fukushima, and Removal of Toxic Metals Using Photosynthetic Bacteria. Journal of Agricultural Chemistry and Environment, 4, 63-75. http://dx.doi.org/10.4236/jacen.2015.43007 


\section{Keywords}

\section{Immobilized Photosynthetic Bacteria, Cs and Sr, Heavy Metals, Removal of Radioactivity, Radioactive Cs, Safe Vegetables}

\section{Introduction}

More than 4 years have passed since March 2011 nuclear accident at the Daiichi Nuclear Power Plant in Fukushima, Japan. The accident released large amounts of radioactive materials that spread throughout the local and regional environments. Radioactive materials contaminated soil, water, and sediment mud of the entire area. The main radioactive materials are Cs radionuclides. The ${ }^{137} \mathrm{I}$ has already disappeared because of its short half life (about 8 days) and the amount of radioactive Sr diffusion from the power plant is quite small [1]. Removal of radioactive Cs from water, sediment mud, and soil of the Fukushima area, therefore, must continue.

Removal of radioactive Cs from water and soil are conducted mainly by physical and chemical approaches using zeolite and clay, and by treatment with some chemicals [1]-[5]. Adsorption treatment using solvents has also been proposed [6]. Recently, new carbon magnetite materials that effectively adsorb radioactive Cs have been reported; in this case the Cs can be recovered with a magnet [7]. However, even after the adsorption of Cs is accomplished, storage facilities for radioactive Cs contaminated wastes are insufficient. Therefore, the developments of technologies that reduce the volume of wastes under treatment are required. In addition, more efficient, convenient and low-cost technologies must be developed in view of the long-term needs for practical removal of radioactivity.

Biological treatment using plants such as sunflowers have been tried, but the effectiveness of removal of radioactivity is insufficient to purify the polluted soil [1] [2].

Regarding the microbiological removal of radioactive Cs, many reports have already described the use of a fungus, Paxillus involutus [8], and cyanobacteria, Synecchocystis PCC 6803 [9], and Rhodococcus erythripolis and Rhodococcus sp. [10]. However, practical removal of Cs using those means has not been reported. Nevertheless, removal of Cs radionuclides from the soil of Fukushima, including removal by physical and chemical processes, has not been conducted. Removal of radioactivity in Fukushima has so far involved the transfer of the polluted surface soil to another location, commonly to a storage facility.

In addition, the heavy metals pollution that accompanied the development of major industries such as chemical, electronics, battery, mining and chemical fertilizers in the past 20 - 40 years, had become a serious environmental problem in Japan [11]. For example, the two toxic metals, mercury and cadmium, released from such industries created significant human tragedies by causing Minamata and ItaiItai deseases [2] [3] [12], respectively. Such toxic heavy metals pollution is currently causing considerable problems in developing countries [12]. In addition, arsenic and mercury pollution in drinking water derived from some aquifers have caused significant public health problems in some localized areas in Asian countries [12].

This article provides a review of practical removal of radioactive Cs from water, sediment mud and soil of Fukushima, carried out by the use of SSI immobilized ceramic and beads using a procedure that is reported earlier [2] [3] [12] [13]. Toxic and heavy metals removal from water are also described [12]. In addition, safe vegetables cultivation using remediated soil is described.

\section{Tri-Pot Porous Ceramic and Ceramic Made from Waste Glass to Adsorb Cs, $\mathrm{Sr}$ and Heavy Metals}

Newly developed tri-pot porous ceramic beads were used for recovery of Cs, Sr, and toxic and heavy metals from Nagao Co. Ltd., Okayama [12]. However, in order to make the recovery of the porous ceramic beads with the electromagnet easier, one of the branches of the tri-pot porous ceramic contains about $5 \%$ iron $(\mathrm{Fe} \mathrm{g/g} \mathrm{SiO} 2)$ (Figure 1). This tri-pot ceramic was hand made using a special paper mold, after mixing $\mathrm{SiO}_{2}$ with a binder (polystyrene) [12]. Recovery of this immobilized ceramic material after bioremediation of metals related to radionuclides, and removal of toxic and heavy metals became possible with an electromagnet. The porous ceramic beads can be recycled and used many times. 


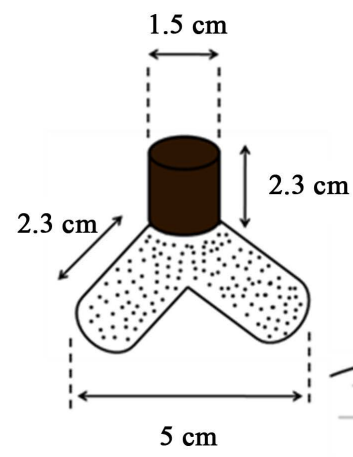

(a)

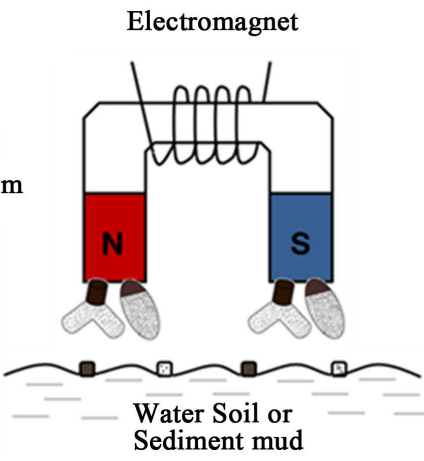

(b)

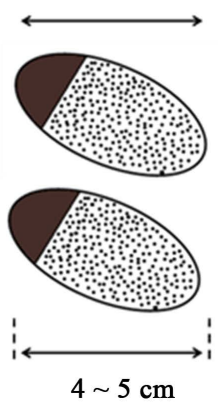

(c)

Figure 1. Porous ceramic tri-pot (a) carrier for recovery made from $\mathrm{SiO}_{2}$ and waste glass (c). The position of the porous ceramic beads shown in black contains 5\% iron for recovery by an electromagnet (b). Photosynthetic bacterium, Rhodobacter sphaeroides strain SSI immobilized ceramic was recovered from water, soil and sediment mud, using an electromagnet (b) after removal of Cs and Sr.

In addition, we used a commercial porous ceramic (Super Sol L1; COCO Co. Ltd., Higashi-Hiroshima, Japan) produced from glass waste [13]. This ceramic, with small block pieces used here, (Figure 1) is 4 to $5 \mathrm{~cm}$ long (about 1 -mm pore size, specific gravity of $\cong 0.4$, and water absorbance of $\cong 10 \%$ ). We converted this ceramic beads to a magnetic recovery type ceramic beads by the addition of iron and a binder solution (Figure 1).

\section{Uranium Adsorption and COD Removal by SSI Immobilized Porous Ceramic}

Figure 2 shows the uranium (U) removal ability of immobilized ceramic beads [12] from water. With strain SSI, the maximum efficiency of removal attained was $97 \%$ after 5 days. From 1 - 8 pieces of immobilized ceramic beads also actively removed COD and phosphate. In the absence of $U$, removal of COD and phosphate by 4 pieces, showed results that were almost identical to those results in Figure 2 (data not shown). Sr and Co were also removed more than $50 \%$ [12].

Assuming the cell number to be constant in and on the ceramic beads ( $0.9 \mathrm{~g}$ cells), concentrations of Sr, Co and $U$ in and on the cells were calculated to be $3.5 \mathrm{mg} / \mathrm{g}$ cells, $3.3 \mathrm{mg} / \mathrm{g}$ cells and $5.1 \mathrm{mg} / \mathrm{g}$ cells, respectively. The amount of Sr adsorbed by cells [12] of Citrobacter sp. was $383 \mathrm{mg} / \mathrm{g}$ cells. Strain SSI possessed a relatively low ability for adsorption of Sr. However, $\mathrm{U}$ is adsorbed almost to the same extent on Asperugillus terreus (1 $\mathrm{mg} / \mathrm{g}$ cells) and Pseudomonas fluorescence (6 mg/g cells) [12]. No data are available for comparison on Co adsorption.

\section{Removal of Toxic and Heavy Metals by SSI Immobilized Ceramic Beads}

In Figure 3, results of the removal of toxic and heavy metals of $\mathrm{Cu}, \mathrm{Hg}, \mathrm{Cr}$, and As by 1 - 4 pieces of immobilized ceramic beads are shown [12]. With 2 - 4 pieces of immobilized ceramic beads, metals were removed relatively rapidly by strain SSI, especially Hg and Cr. During the removal of Hg, COD and phosphate removal showed almost identical behavior as $U$, therefore, this immobilized system seems to be applicable to the removal of a wide range of heavy metals and other metals. However, as showed a strong toxic effect for strain SSI at a concentration of $20 \mathrm{mg} / \mathrm{L}$. At a concentration of $2 \mathrm{mg} / \mathrm{L}$ As could be removed well, as shown in Figure 3(d).

We have previously reported Cd removal by photosynthetic bacteria with extracellular polymeric substances (EPS) which can adsorb cations of heavy metals on their negative charges using Friedlich adsorption isotherm [14]. We observed a similar phenomenon among U, Sr, Co, Hg and Cr removal using immobilized system, although the entrap effect of EPS by its mucous characteristics for removal of metals were not examined. Alginate gel cannot adsorb such metals. Such cationic metals removal seems to have occurred by EPS negative charge just as the $\mathrm{Cd}$ adsorption phenomenon. This phenomenon seems to be applicable for bioremediation of a variety of toxic and heavy metals, and metals related to radionuclides. As regards As, it is not always present as cation in an aquatic phase, therefore, both effects (negative charge and entrap effect of EPS) seem to have played a role in the removal experiment. 


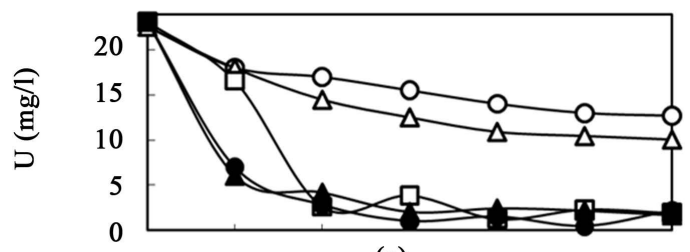

(a)

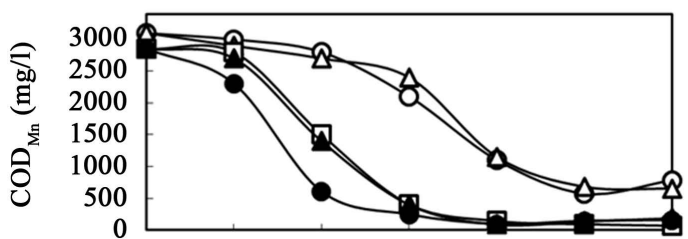

(b)

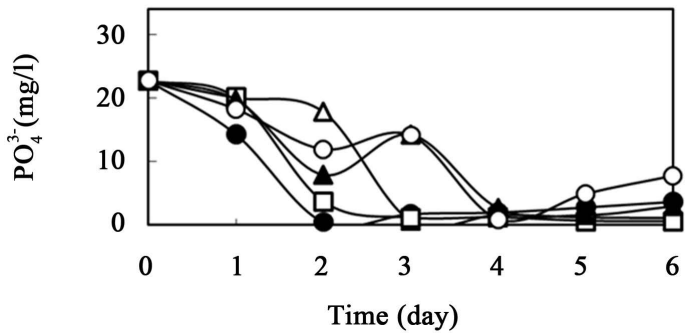

(c)

Figure 2. Profiles of $\mathrm{U}, \mathrm{COD}$ and $\mathrm{PO}_{4}^{3--}$ in synthetic sewage wastewater containing $\mathrm{U}$, using strain SSI immobilized ceramic under aerobic dark condition. $\circ$, Control (aeration only); $\Delta$, porous ceramic 4 pieces; $\square$, strain SSI immobilized ceramic 1 piece; $\boldsymbol{\Delta}$, strain SSI immobilized ceramic 4 pieces; $\bullet$, strain SSI immobilized ceramic 8 pieces.

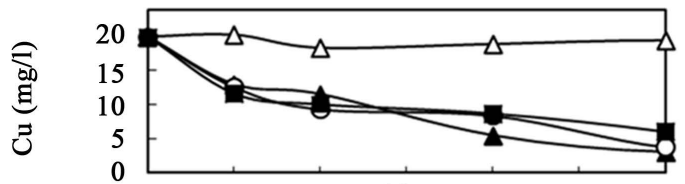

(a)

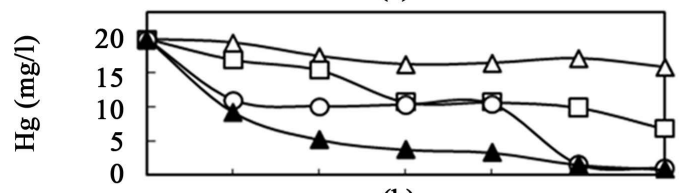

(b)

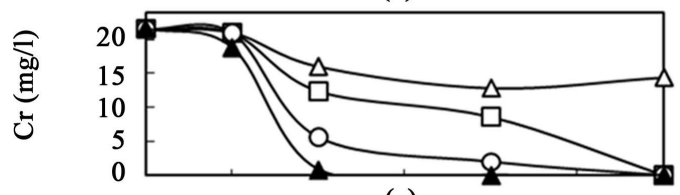

(c)

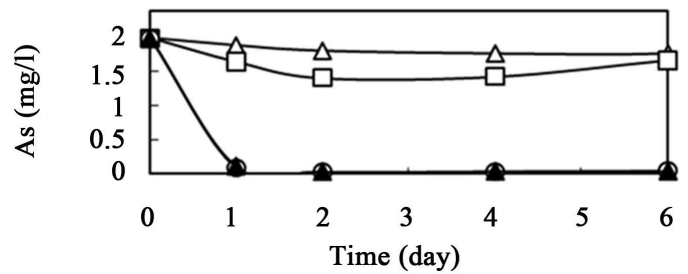

(d)

Figure 3. $\mathrm{Cu}, \mathrm{Hg}, \mathrm{Cr}$, and As removal with strain SSI immobilized ceramic from synthetic sewage wastewater of glucose $(4 \mathrm{~g} / \mathrm{L})$ under aerobic dark condition. $\Delta$, porous ceramic 1 piece; $\square$, strain SSI immobilized ceramic 1 piece; $\circ$, strain SSI immobilized ceramic 2 pieces; $\boldsymbol{\Delta}$, strain SSI immobilized ceramic 4 pieces. 


\section{Simultaneous Removal of Cs and Sr by SSI Immobilized Ceramic Beads}

Using 4 - 8 pieces of SSI immobilized ceramic per 1 L of synthetic wastewater, simultaneous removal of Cs and Sr was investigated in an indoor incubator $\left(30^{\circ} \mathrm{C}\right)$ [13].

As presented in Figure 4(a), Cs was removed almost 100\% after 3 days with 4 and 8 pieces of SSI immobilized ceramic beads. The ceramic, made from waste glass, was not able to absorb $\mathrm{C}$ sand alginate cannot adsorb Cs [13], therefore, the SSI cells absorbed the Cs. As far as Sr removal is concerned, 57\% - 61\% Sr removal was observed with 4 - 8 pieces of SSI immobilized ceramic beads after 3 days, as shown in Figure 4(b). Sr also cannot be absorbed by alginate [13]. Although Sr removal was insufficient, simultaneous removal of Cs and Sr was successful using SSI immobilized ceramic beads. In fact, Cs and Sr can be removed effectively and simultaneously from water with SSI immobilized cells [13].

\section{Effects of Potassium on Removal of Cs and $\mathrm{Sr}$}

During preliminary Cs and Sr removal experiments, Cs removal was highly variable (data not shown). However, since Jasper [15] reported that Cs was mainly incorporated by the K transport system of the photosynthetic bacterium, Rhodopseudomonas capsulate, we investigated the effects of K concentration on the removal of Cs and Sr.

As shown in Figure 5(a) [13], Cs removal was affected by K concentration. With high concentrations of K, i.e. $6.70 \mathrm{mg} / \mathrm{L}$, which is the standard concentration of $\mathrm{K}$ in synthetic wastewater, Cs removal was suppressed compared with that of a low concentration of K (i.e. 0 - $3.35 \mathrm{mg} / \mathrm{L}$ ). On the other hand, the $\mathrm{K}$ concentration did not affect Sr removal (Figure 5(b)), similar to what was observed with $R$. capsulata [5].

\section{A New Process for Removal of Radioactivity and Recovery of Radioactive Cs by Immobilized $R$, sphaeroides, SSI}

A new process to remove radioactivity from sediment mud and soil has been developed by us [2] [3]. As shown in Figure 6, radioactively polluted sediment mud and soil are diluted with water. This soil is treated by addition

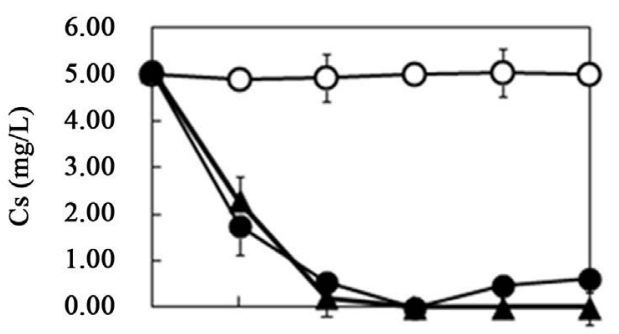

(a)

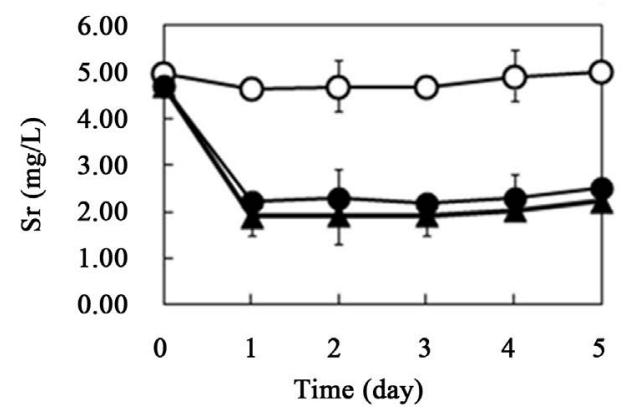

(b)

Figure 4. Cs and Sr removal by $R$. sphaeroides SSI immobilized in ceramic beads from synthetic wastewater of glucose ( $4 \mathrm{~g} / \mathrm{L})$ as a substrate. 4 - 8 pieces of SSI immobilized ceramic beads were used in synthetic wastewater $(\mathrm{K}=1.75 \mathrm{mg} / \mathrm{L})$ in a $1 \mathrm{~L}$ vessel and aerated $(0.2-0.5 \mathrm{vvm})$ at $30^{\circ} \mathrm{C}$ : a: Cs (initial, $5 \mathrm{mg} / \mathrm{L}$ ), b: Sr (initial, 5 $\mathrm{mg} / \mathrm{L}$ ). $\circ$, control (4 pieces of ceramic without SSI cells); $\bullet, 4$ pieces of SSI immobilized ceramic; $\boldsymbol{\Lambda}, 8$ pieces of SSI immobilized ceramic. 


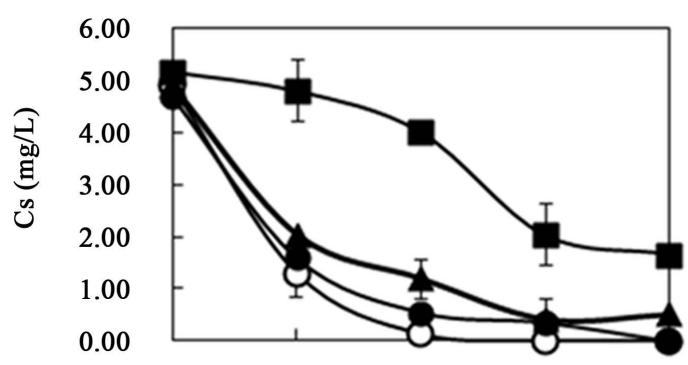

(a)

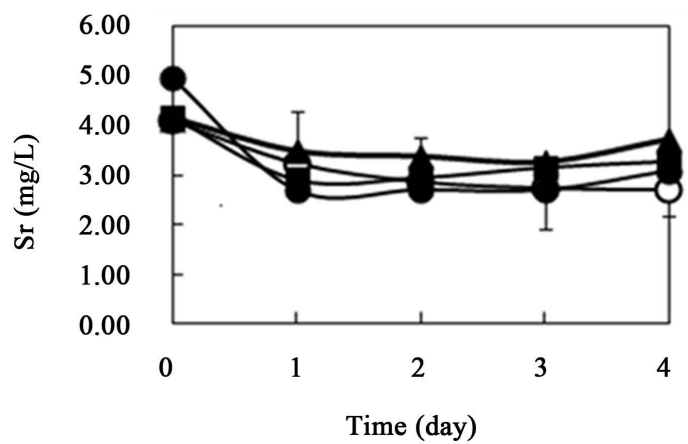

(b)

Figure 5. Effect of K concentration on removal of Cs and Sr by R. sphaeroides SSI immobilized ceramic from synthetic wastewater of glucose $(4 \mathrm{~g} / \mathrm{L})$ as a substrate. 4 pieces of SSI immobilized ceramic were put in $1 \mathrm{~L}$ synthetic sewage wastewater. Then aeration $(0.2-0.5 \mathrm{vvm})$ was conducted at $30^{\circ} \mathrm{C}$. a: Cs (initial, $5.0 \mathrm{mg} / \mathrm{L}$ ), b: $\mathrm{Sr}$

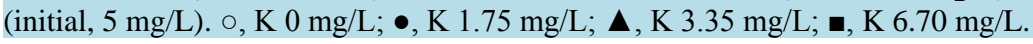
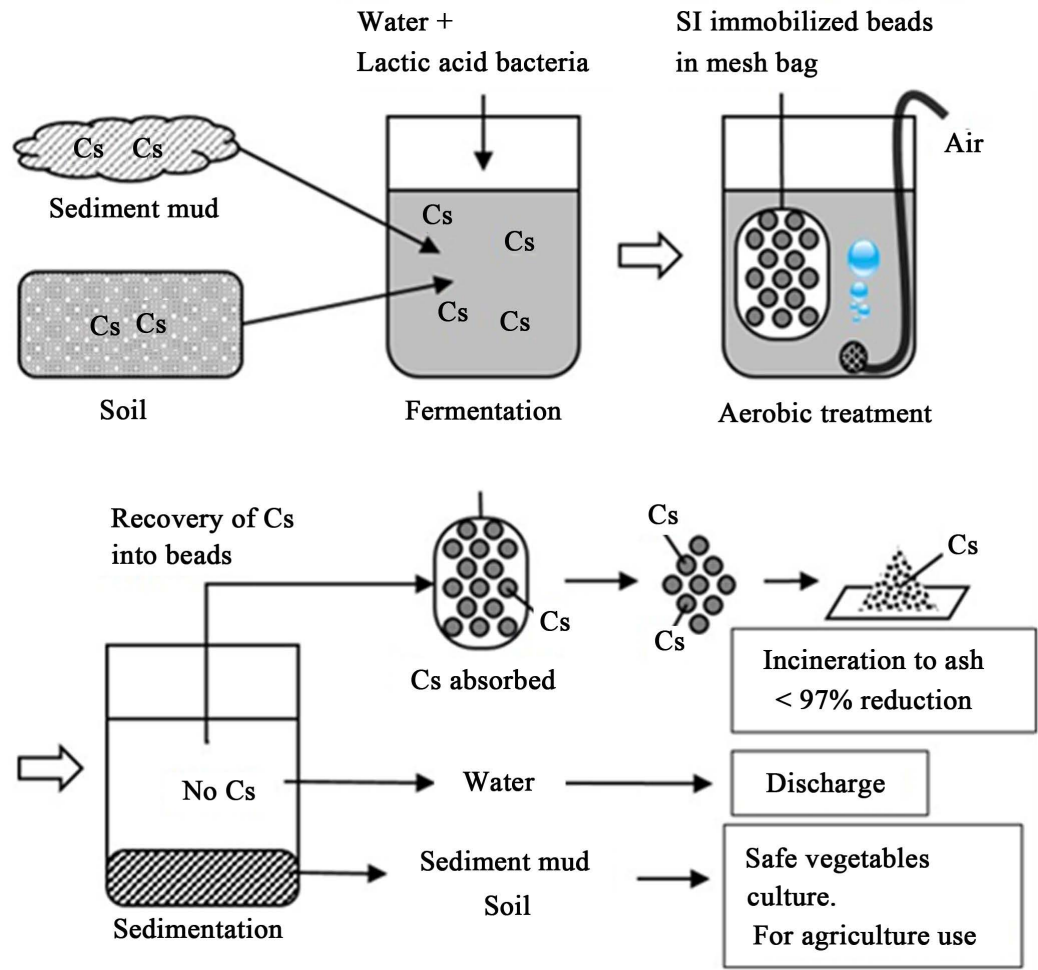

Figure 6. Removal and recovery of radioactive Cs from sediment mud or soil, and reduction of volume and weight $(<97 \%)$. 
of a culture broth of lactic acid bacteria. Lactic acid fermentation and anaerobic digestion were carried out for a period of 4 - 5 days. After that, immobilized SSI beads packed in a mesh bag (about 200 pieces) were added together with nutrients [2] (glucose $200 \mathrm{~g}$, peptone $7 \mathrm{~g}$ and vitamin mixture $\left(\mathrm{B}_{1} \mathrm{HCl}, 50 \mathrm{mg} / \mathrm{L}\right)$ and nicotinic acid $(50 \mathrm{mg})$ and biotin $(5 \mathrm{mg})$ ). Aerobic treatment was carried out with aeration of $0.2-0.3 \mathrm{vvm}$ for about 15 days. After 3 - 4 days of aeration, the mesh bag was replaced by one containing fresh immobilized beads, and aeration was continued. The SSI beads containing recovered radioactive Cs were incinerated to ash. By this treatment, the mass of the beads was reduced by more than $97 \%$ [3]. This is the single biggest advantage of this treatment, as unlike other more complex protocols, this approach does not require a storage facility. This process is compact, easy and simple in Fukushima, Japan. Following uptake of the radioactive metals, the water no longer contains any radioactive Cs. In addition, it is possible that treated soil or sediment mud after Cs recovery can be recycled, and used for vegetable cultivation. Quite low radioactive vegetables (safe vegetables) can be cultivated by this removal process.

Treatment of sediment mud involved mixing of $30 \mathrm{~kg}$ of sediment mud with $20 \mathrm{~L}$ of water, after sediment mud was pre-treated for one day by $\mathrm{HNO}_{3}$ (conc.) addition until the broth reached to $\mathrm{pH}$ 2.0.

In Photo 1, the removal of radioactivity from soil from Fukushima, Japan (c) with immobilized SSI strain beads $(a, b)$ is shown.

\section{Removal of Radioactive Cs from Polluted Sediment Mud}

The results of an attempt to remove radioactive Cs in three batch experiments are shown in Figure 7 [3]. After 3 days, radioactivity in the first batch decreased from $14.35 \mu \mathrm{Sv} / \mathrm{h}$ to $2.60 \mu \mathrm{Sv} / \mathrm{h}(81.9 \%$ reduction). Radioactivity of this area was $1.20 \mu \mathrm{Sv} / \mathrm{h}$ in the air. This result is almost the same as that for removal of non-radioactive Cs with alginate- and ceramic-immobilized SSI cells, as previously reported [13]. Alginate is also unable to adsorb radioactive Cs [3]. This removal of radioactivity is due to the activity of strain SSI.

To date, there have not been any reports of removal of more than $80 \%$ of radioactive Cs by a practical microbiological treatment [9]-[11]. In addition, when fresh sediment mud $\left(\mathrm{HNO}_{3}\right.$ treated) was used for treatment (the second batch) with the same immobilized cells, after 1 day, the radioactivity of the liquid decreased to 2.95 $\mu \mathrm{Sv} / \mathrm{h}$. Thus the immobilized cells remained active in the second batch. After three batches, the SSI strain was still active in removing Cs, even at relatively low temperatures. In the second and third batches, the removal rates were $75.6 \%$ and $73.2 \%$ respectively (Figure 7 ) although the SSI strain has an optimum growth at $25^{\circ} \mathrm{C}$ $35^{\circ} \mathrm{C}$. Alginate is also unable to adsorb radioactive Cs [3].

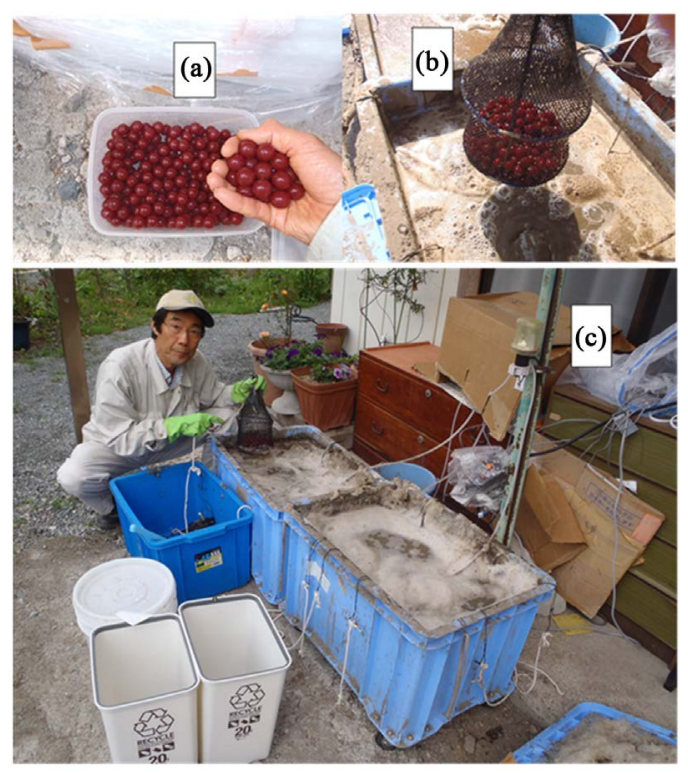

Photo 1. Removal of radioactivity from soil in Fukushima, Japan using SSI immobilized beads in a $60 \mathrm{~L}$ container (c). (a) SSI beads; (b) SSI beads in mesh bag. 


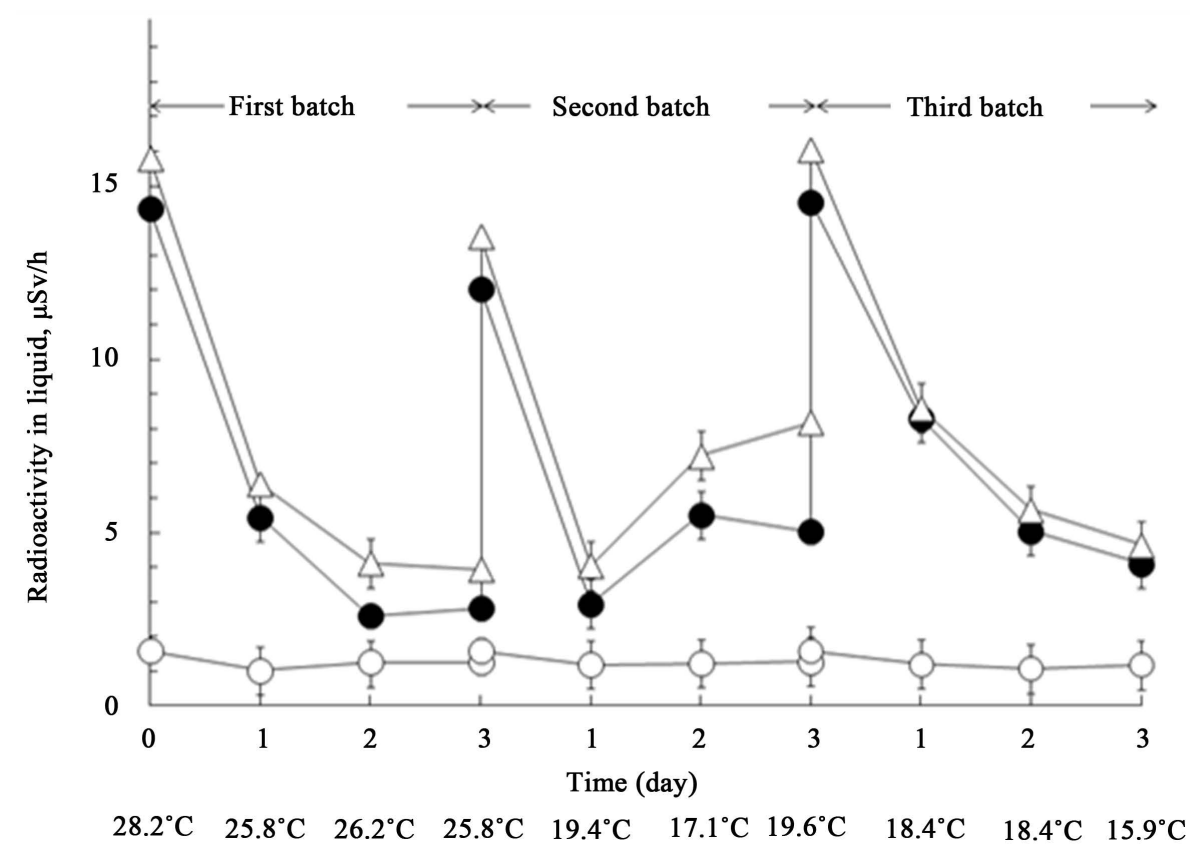

Figure 7. Removal of radioactive Cs from sediment mud obtained from a school swimming pool solubilized by acid $\left(\mathrm{HNO}_{3}\right)$ by repeated batch treatment with the same immobilized $R$. sphaeroides SSI cells. After the first two treatments, fresh sediment mud solubilized by acid was placed in a $60 \mathrm{~L}$ container with glucose and peptone, and aeration was continued. The vessel temperatures at $10 \mathrm{AM}$ each day are shown. $\bullet$, radioactivity in broth; $\Delta$, radioactivity of sediment residue after filtration; $\odot$, radioactivity in filtrated water.

Surprisingly, Cs was entirely absent from the filtrated water (Figure 7). Radioactivity in the water is almost the same as background value $(0.12-0.14 \mu \mathrm{Sv} / \mathrm{h})$ and radioactivity was present in the sediment residue moiety [3]. Cs appeared to be strongly bound to the sediment mud. It was apparently removed by photosynthetic bacterial (SSI strain) activity.

Removal of Cs from concentrated sediment mud (without $\mathrm{HNO}_{3}$ treatment) was also carried out in batch treatment (Figure 8(a)) [3] using the same experimental procedure as that shown in Figure 7, but almost the same results were obtained as shown in that figure. The results shown in Figure 8(a) suggest that radioactive Cs in sediment mud from a swimming pool can be removed by an SSI strain without acid treatment. Figure 8(b) shows treatment with half the amount of SSI cells. The only difference between Figure 7 and Figure 8(b) is that the cell amount was reduced by half. Although the amount of radioactive Cs removed was insufficient, Cs in sediment mud was removed even under low temperature with half the amount of immobilized cells. Accordingly, the SSI cells needed to remove Cs can be reduced in consideration of shown practical costs, but detailed optimum conditions must be elucidated. The results in Figure 8 suggest the possibility of practical removal of radioactive Cs from water, organic sediment mud, and soil.

One advantage of alginate-immobilized SSI cells is a reduction in biomass due to drying and incineration. Harvested immobilized cells after three rounds of treatment (Figure 7), which were easily performed with a mesh bag, were dried in an oven at $80^{\circ} \mathrm{C}-90^{\circ} \mathrm{C}$ for 3 days. During drying, no radioactivity increase was observed in the air. But, biomass was reduced by $97.2 \%$ (w/w) [3] after drying from the original immobilized beads. After incineration, the biomass became ash, and the biomass weight was reduced by $99.3 \%$ compared tothe original immobilized beads (wet base). Moreover, the mass of the biomass was reduced by $98.3 \%(\mathrm{v} / \mathrm{v})$.

\section{Removal and Recovery of Radioactivity from Soil}

The soil around Fukushima is still polluted by radioactivity and cannot be used for agriculture. A large amount of surface soil from this area is kept in large bags, and is accumulating in storage facilities. These bags of surface soil were transferred from various areas to temporarily reduce radioactivity in the air. Some bags have broken and subsequent leakage of radioactivity has caused new pollution of waters around the river mouth. Although 


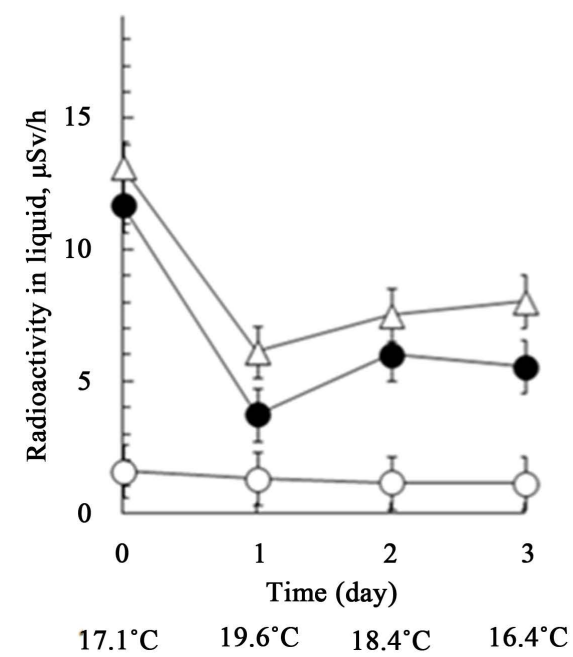

(a)

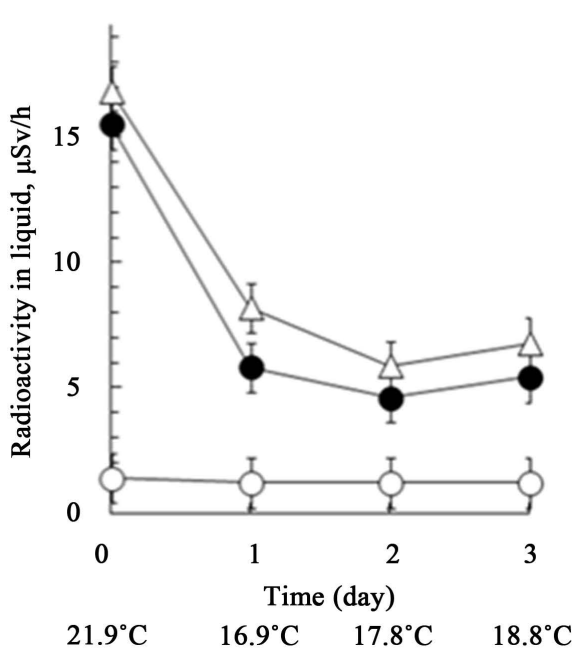

(b)

Figure 8. Removal of radioactive Cs from concentrated sediment mud directly (without $\mathrm{HNO}_{3}$ treatment) (a) and removal of radioactive Cs from sediment mud solubilized by acid (with conc. $\mathrm{HNO}_{3}$ treatment at $\mathrm{pH} 2.00$ for 1 day) using half the amount of immobilized SSI cells (b). The vessel temperatures at 10 am each day are shown. Symbols are identical to those used in Figure 7.

the removal of radioactivity from soil was essential, the government of Japan did not carry out removal of radioactivity from soil rather radioactivity was removed by simple transfer of surface soil of moderately polluted areas to more heavily polluted sites, generally close to the Daiichi Nuclear Power Plant of Fukushima.

In order to reduce soil radioactivity, anaerobic digestion and lactic acid fermentation of soil suspended broth by SSI immobilized bead treatment was conducted. As shown in Figure 9 [2], when two and three bags were soaked in soil suspended broth, the initial radioactivity of the soil suspended broth $(7.33 \mu \mathrm{S} v / \mathrm{h})$ was reduced to 3.64 (2 bags) and 3.42 (3 bags) (about a 53\% reduction) after 14 days. This is greater than that of the SSI immobilized bead treatment alone (without lactic acid bacteria addition, yielded a 31\% reduction after 15 days) [2]. Furthermore, radioactivity was reduced to 3.18 (2 bags) and 3.02 (3 bags) $(\mu \mathrm{S}$ v/h, maximum 59\% reduction after 24 days). The radioactivity was slightly reduced by the addition of fresh SSI immobilized beads. Radioactive Cs was almost absorbed and incorporated as the low-molecular-weight material which was easily absorbed and incorporated by SSI cells during the first SSI immobilized beads soaking. Anaerobic digestion and lactic acid fermentation appear to enhance the release of radioactive Cs into small soil particles and enhance adsorption and incorporation of Cs into SSI cells.

\section{Outdoor Removal of Radioactivity from Soil}

Outdoor removal of radioactivity from soil using a $60 \mathrm{~L}$ container was carried out after anaerobic digestion and lactic acid fermentation by addition of lactic acid. SSI immobilized beads treatment was conducted under aerobic condition (Figure 10) [16]. The radioactivity of suspended broth of soil of $6.18 \mu \mathrm{Sv} / \mathrm{h}$ was reduced to 2.19 Sv/h after 14 days of aerobic treatment; finally a removal of $52.9 \%$ was obtained. By replacing old SSI beads by fresh ones after 9 days, a slight reduction of radioactivity was observed in the suspended broth. However, when Bq unit evaluation of soils was carried out, 199,248 Bq/kgdw (dw: dry weight) of polluted soil before treatment was reduced to $72,225 \mathrm{~Bq} / \mathrm{kgdw}$ after treatment, that is, $64.0 \%$ removal could be obtained. Radioactive Cs was adsorbed or incorporated into SSI beads during aerobic treatment. $63.8 \%$ removal and recovery of radioactivity from soil is a significant fact in the practical biotechnological process [8]-[14].

Lactic acid bacteria were added to enhance the removal of radioactivity from soil. Without the addition of lactic acid bacteria, removal of radioactivity from soil with immobilized SSI was only 31\% [2]. However, with the addition of lactic acid bacteria, the removal rate was increased up to 66.6\% [2]. Lactic acid bacteria broke down large organic molecules while strain SSI appeared to consume the digested organic material and also took up the radioactive Cs into the immobilized cells. Thus radioactive removal was more effective by the dual treatment. 


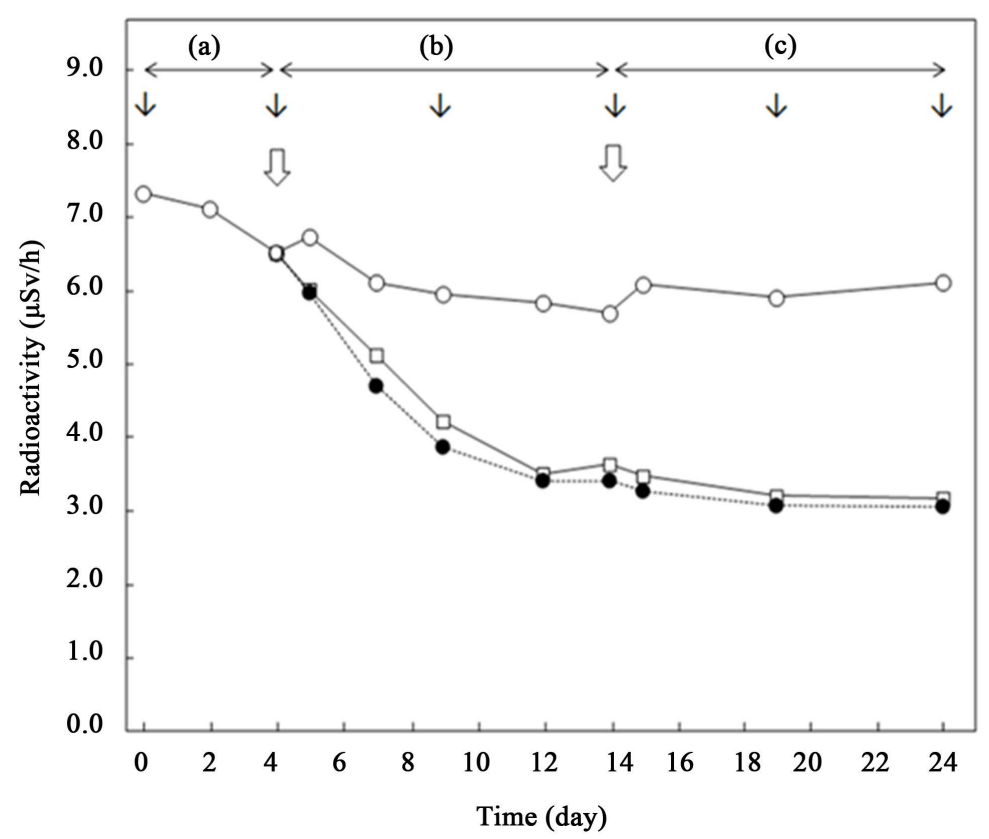

Figure 9. Removal of radioactivity from soil suspended broth by a combination of anaerobic digestion, lactic acid fermentation, and Rhodobacter sphaeroides SSI immobilized bead treatment from polluted soil suspended broth. Pre-treatment included, anaerobic digestion and lactic acid fermentation, conducted for $3 \mathrm{~d}$ (a) at $35^{\circ} \mathrm{C} \pm 1.0^{\circ} \mathrm{C}$ after lactic acid bacterial broth and nutrient (glucose, peptone, and vitamins) addition to the soil suspended broth (5 kg soil and $10 \mathrm{~L}$ tap water). Subsequently 2 - 3 mesh bags of SSI immobilized beads were soaked and aeration of 0.2 0.3 vvm was continued under the same conditions. Temperature and $\mathrm{pH}$ were maintained, respectively, at $30^{\circ} \mathrm{C} \pm 1.0^{\circ} \mathrm{C}$ and 6.0 - 7.5: (a) pre-treatment, anaerobic digestion and lactic acid fermentation; (b) first treatment after SSI immobilized beads addition; (c) second treatment after fresh SSI immobilized beads bags soaked. Solid arrows and open arrows indicate nutrient addition and SSI immobilized mesh bag addition, o, control (no mesh bags of SSI) addition; $\square, 2$ mesh bags added; $\bullet, 3$ mesh bags added.

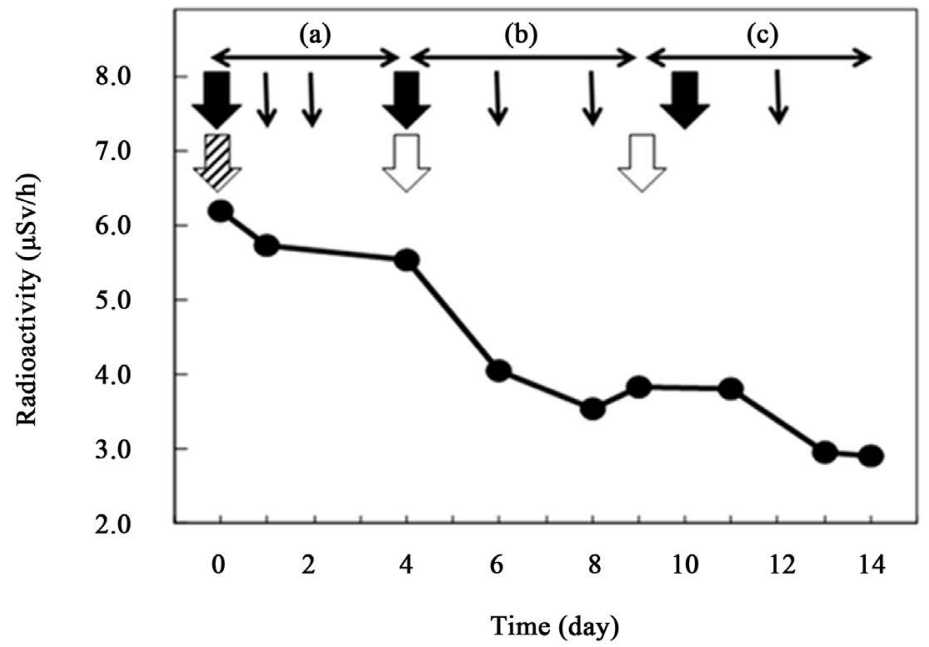

Figure 10. Practical removal and recovery of radioactivity from polluted soil in Fukushima using immobilized SSI strain. $30 \mathrm{~kg}$ soil was mixed with water and lactic acid bacterial broth (60 L), lactic acid and anaerobic fermentation was carried out (a); Aeration (0.2 - $0.3 \mathrm{vvm}$ ) was continued, 9 mesh bags (about 200 beads) were put in container (b) and replaced by fresh SSI beads (c). Large closed arrow, nutrients (glucose, peptone and vitamins) added; arrow, glucose added; Large slash arrow, lactic acid added; Large open arrow, mesh bag of beads added. 
For removal of radioactive Cs, physical treatments such as zeolite and clay treatments [1] [2] are frequently applied. However, such treatments are ineffective because the release of Cs from soil is rather difficult, and a large amount of treated radioactive wastes presents a problem of waste storage. Removal of radioactive Cs using chemicals, moreover, is also problematic in agricultural fields because of the chemicals' chronic toxic effects for plants and human beings. On the other hand, biological treatments such as phytoremediation and the process described in this manuscript are apparently amenable for removal of radioactivity from agriculture fields.

As summarized in Table 1, removal and recovery of radioactivity by immobilized SSI strain from sediment mud was $73.2 \%-81.9 \%$. These experiments were carried out without the addition of lactic acid bacteria. In addition, removal of radioactivity from soil were 59.5\% - 73.3\%. Removal of radioactivity from soil was rather difficult compared with sediment mud. However, these data were obtained in the outdoor practical treatment.

\section{Posturated Mechanism of Cs Removal by Immobilized SSI Strain}

The total ability of the SSI strain to attract $\mathrm{Cs}^{+}$appeared to be relatively strong compared to the binding power of $\mathrm{Cs}^{+}$to sediment mud. The mechanism of $\mathrm{Cs}^{+}$attraction is assumed to operate as follows: First, a negative charge of EPS (Extracellular Polymeric Substances), produced on the surface of photosynthetic bacteria of the SSI strain adsorbs $\mathrm{Cs}^{+}$, as described [12] [13]. In addition, the potassium transport system of the SSI strain seem to be strong for $\mathrm{Cs}^{+}$uptake as shown by cyanobacterium Synecosystis PCC 6803, [9] and by Rhodococcus erythropolis CS98 [10]. Jasper [15] reported that a photosynthetic bacterium, Rhodopseudomonas capsulate, uptakes mainly $\mathrm{Cs}^{+}$by a potassium transport system. This cell cannot produce EPS on its surface [15]. We suggest the involvement of the potassium transport system in SSI cells as shown in Figure 5 and elsewhere [13]. Hence, we speculate that the SSI strain takes up $\mathrm{Cs}^{+}$on and into immobilized cells by the negative charge of EPS and the potassium transport system.

Toxic and heavy metal uptake such as $\mathrm{Cd}, \mathrm{Pb}, \mathrm{Cr}, \mathrm{Hg}$, As and $\mathrm{Cu}$ adsorption by immobilized SSI cells may proceed by minus charge of EPS from SSI cells [12]. The potassium transport system of SSI strain is stronger compared with other bacteria. Therefore, radioactive Cs can be preferentially taken up by SSI cells in the presence of added potassium.

\section{Vegetable Cultivation on Soil Stripped of Radioactivity}

One main purpose of removal of radioactivity from soil was to make the soil suitable for agriculture. Cultivation of vegetables was carried out on SSI treated soil. Vegetables grew well on pots filled with SSI treated soil, just like vegetables would grow in normal cultivation. As shown in Table 2, when highly polluted soil D (36,490 $\mathrm{Bq} / \mathrm{kgdw}$ ) was treated by SSI beads, $73.7 \%$ of the radioactivity was removed. Vegetables such as Komatuna (Turrip leaf, Brassica rapa var. pervidis) and Chingensai (Green pakchoi, Brassica rapa var. chinensis) cultivated on soil after SSI treatment, demonstrated radioactivity of only 107 to $78 \mathrm{~Bq} / \mathrm{kgfw}$ which were almost identical to or lower than the recommended value for edible food in Japan $(<100 \mathrm{~Bq} / \mathrm{kgfw})$. When culture broth of SSI strain was used for removal of radioactivity, the rate of removal was $61.6 \%$ (Table 2). However, vegetables grown on the soil after SSI treatment showed radioactivity which were ND (not detected, for Komatuna), and 50

\begin{tabular}{|c|c|c|c|c|c|c|c|}
\hline Sediment & mud & Radioactivity & Removal (\%) & Soil & \multicolumn{2}{|c|}{ Radioactivity } & Removal (\%) \\
\hline \multirow[t]{2}{*}{ A } & Before & $14.35 \mu \mathrm{Sv} / \mathrm{h}$ & & A & Before & $10.56 \mu \mathrm{Sv} / \mathrm{h}$ & \\
\hline & After & $2.60 \mu \mathrm{Sv} / \mathrm{h}$ & 81.9 & & After & $3.52 \mu \mathrm{Sv} / \mathrm{h}$ & 66.6 \\
\hline \multirow[t]{2}{*}{ B } & Before & $12.07 \mu \mathrm{Sv} / \mathrm{h}$ & & B & Before & $199,248 \mathrm{~Bq} / \mathrm{kg}$ & \\
\hline & After & $2.95 \mu \mathrm{Sv} / \mathrm{h}$ & 75.9 & & After & $72,225 \mathrm{~Bq} / \mathrm{kg}$ & 64.0 \\
\hline \multirow[t]{4}{*}{ C } & Before & $15.20 \mu \mathrm{Sv} / \mathrm{h}$ & & C & Before & $87,181 \mathrm{~Bq} / \mathrm{kg}$ & \\
\hline & After & $4.60 \mu \mathrm{Sv} / \mathrm{h}$ & 73.2 & & After & 35,340 Bq/kg & 69.5 \\
\hline & & & & $\mathrm{D}$ & Before & $36,490 \mathrm{~Bq} / \mathrm{kg}$ & \\
\hline & & & & & After & 9,855 Bq/kg & 73.3 \\
\hline
\end{tabular}


Table 2. Safe vegetables which showed lower radioactivity compared with edible food regulation in Japan using soils with SSI beads and culture broth treated and original soil.

\begin{tabular}{|c|c|c|c|c|c|c|}
\hline \multirow{2}{*}{$\begin{array}{l}\text { Soil } \\
D^{3)}\end{array}$} & \multirow{2}{*}{$\begin{array}{c}\text { Removal Method } \\
\text { Beads }\end{array}$} & \multicolumn{2}{|c|}{ Radioactivity of soil $(\mathrm{Bq} / \mathrm{kgdw})^{1)}$} & \multirow[t]{2}{*}{ Radioactivity removal (\%) } & \multicolumn{2}{|c|}{ Radioactivity of vegetables $(\mathrm{Bq} / \mathrm{kgfw})^{2)}$} \\
\hline & & Before & 36,490 & & Kom: 454 & Chin: 324 \\
\hline & & After & 9,855 & 73.3 & Kom: 107 & Chin: 78 \\
\hline & Broth & After & 14,366 & 61.6 & Kom: ND & Chin: 50 \\
\hline \multirow[t]{2}{*}{$\mathrm{E}$} & Broth & Before & 13,602 & & Kom: 477 & Chin: 502 \\
\hline & & After & 7.315 & 45.1 & Kom: 63 & Chin: 57 \\
\hline
\end{tabular}

${ }^{1)} \mathrm{dw}$ : dry weight; ${ }^{2)}$ fw: fresh weight ${ }^{3)}$. Same soil in Table 1 D; Kom: Komatuna (Turrip leaf) Chin: Chingensai (Green pakchoi); Edible food regulation for vegetables in Japan: <100 Bq/kgfw; For infant: <50 Bq/kgfw).

$\mathrm{Bq} / \mathrm{kgfw}$ for Chingensai, were the same or less than the recommended value for edible food for infants in Japan (50 Bq/kgfw). On the other hand, vegetables cultivation using untreated soil (i.e. the soil before treatment) showed high radioactivity of vegetables such as 324 - 502 Bq/kgfw which values have highly exceed for edible food of Japan (Table 2).

Here the cultivation of vegetables included the use of commercial liquid fertilizer. By the treatment with the SSI strain, radioactive Cs (preferred for vegetables growth) almost completely removed from the soil preferencially, and almost no radioactive Cs was transferred into the vegetables grown. In addition, when soil E (13,602 $\mathrm{Bq} / \mathrm{kgdw}$ ) was treated with SSI culture broth, the rate of removal was relatively low (45.1\%) (Table 2). Yet the Komatuna and Chingensai vegetables grown on that soil showed radioactivity as low as 63 Bq/kgfw and 57 $\mathrm{Bq} / \mathrm{kgfw}$, respectively.

To date, the use of such highly polluted soil (more than 30,000 Bq/kgdw) for safe vegetable cultivation, following treatment, has not been reported. Kobayashi [17] reported that radioactively polluted soil of about 15,000 $\mathrm{Bq} / \mathrm{kgdw}$ was used for Komatuna cultivation with zeolite mixed in soil, which produced vegetables containing radioactivity less than $100 \mathrm{~Bq} / \mathrm{kgfw}$. No report, however, had shown the result of vegetable production on soil containing radioactivity of more than $15,000 \mathrm{~Bq} / \mathrm{kgdw}$. Generally, vegetables containing less than $100 \mathrm{~Bq} / \mathrm{kgfw}$ radioiactivity (safe vegetable) could be grown in polluted soils containing radioactivity less than 12,000 Bq/ kgdw, by the use of potassium enriched fertilizer [17], which had been reported to reduce the radioactive Cs content in vegetables [18].

These results were quite significant in the sense that highly polluted radioactive soil could be satisfactorily used for agriculture after treatment by SSI beads or culture broth. Vast quantities of polluted soil were still widely spread, and stock piled in large bags in many large storage facilities in Fukushima. Such polluted soil might be treated and then returned to its original place and subsequently used for agriculture.

We are now applying our radioactivity removal technology to very highly polluted soil (more than 100,000 $\mathrm{Bq} / \mathrm{kgdw}$ ) using SSI entrapped beads and culture broth treatment to remedy the soil and make it suitable for safe vegetable cultivation.

\section{References}

[1] Ministry of Fish and Agriculture (2011) Removal Technology of Radioactive Materials of Soil for Agriculture (Decontamination Technology). Association of the Technology for Agriculture, Forest and Fish. http://www.aist.go.jp/aist_j/press_release/pr2011/pr20110831/pr20110831.html

[2] Sasaki, K., Morikawa , H., Kishibe, T., Takeno, K., Mikami, A., Harada, T. and Ohta, M. (2012) Practical Removal of Radioactivity from Soil in Fukushima Using Immobilized Photosynthetic Bacteria Combined with Anaerobic Digestion and Lactic Acid Fermentation as Pre-Treatment. Bioscience, Biotechnology, and Biochemistry, 76, 1809-1814. http://dx.doi.org/10.1271/bbb.120440

[3] Sasaki, K., Morikawa, H., Kishibe, T., Mikami, A., Harada , T. and Ohta, M. (2012) Practical Removal of Radioactivity from Sediment Mud in a Swimming Pool in Fukushima, Japan by Immobilized Photosynthetic Bacteria. Bioscience, Biotechnology, and Biochemistry, 76, 859-862. http://dx.doi.org/10.1271/bbb.110853

[4] Sugoh, T. (2012) Cesium Adsorption Effect Using High Polymer Adsorption Materials Such as Crown Ether. The Radioactive Contamination Countermeasures after the Great East Japan Earthquake, NTS Publishers, Tokyo, 161-172.

[5] Takeshita, K. (2012) Development of a Treatment System for Cesium Polluted Water. The Radioactive Contamination 
Countermeasures after the Great East Japan Earthquake, NTS Publishers, Tokyo, 173-181.

[6] Seko, N., Suzuki, S. and Yaita, D. (2012) Adsorption Effects of Cesium by High Polymer Sorbent Such as Crown Ehter. The Radioactive Contamination Countermeasures after the Great East Japan Earthquake, NTS Publishers, Tokyo, 204-211.

[7] Yamaguchi, D., Furukawa, D., Takasuga, M. and Watanabe, K. (2014) A Magnetic Carbon Sorbent for Radioactive Materials from the Fukushima Nuclear Accident. Scientific Reports, 4, 6053. http://dx.doi.org/10.1038/srep06053

[8] Haselwandter, K. and Berreck, M. (1988) Fungi as Bioindicators of Radio-Cesium Contamination: Pre- and PostChernobyl Activities. Transactions of the British Mycological Society, 90, 171-174. http://dx.doi.org/10.1016/S0007-1536(88)80085-8

[9] Avery, S.V., Codd, G.A. and Gadd, G.M. (1991) Cesium Accumulation and Interactions with Other Monovalent Cations in the Cyanobacterium synechocystis PCC 6803. Journal of General Microbiology, 137, 405-413. http://dx.doi.org/10.1099/00221287-137-2-405

[10] Tomioka, N., Uchiyama, H. and Yagi, O. (1994) Cesium Accumulation and Growth Characteristics of Rhodococcus erythropolis CS98 and Rhodococcus sp. Strain CS402. Applied and Environmental Microbiology, 60, 2227-2231.

[11] Ohmura, N., Watanabe, Y. and Saiki, H. (1996) Report of Central Research Institute of Electricity. Central Research Institute of Electricity, Tokyo, 1-31.

[12] Sasaki, K., Hara, C., Takeno, T., Okuhata, H. and Miyasaka, H. (2010) Metals Related to Radionuclides and Heavy Metal Removal Using Photosynthetic Bacteria Immobilized Recovery Type Porous Ceramic. Japanese Journal of Water Treatment Biology, 46, 119-127.

[13] Sasaki, K., Morikawa, H., Kishibe, T., Takeno, K., Mikami, A., Harada, T. and Ohta, M. (2012) Simultaneous Removal of Cesium and Strontium Using a Photosynthetic Bacterium, Rhodobacter sphaeroides SSI Immobilized on Porous Ceramic Made from Waste Glass. Advances in Bioscience and Biotechnology, 4, 6-13. http://dx.doi.org/10.4236/abb.2013.41002

[14] Watanabe, M., Kawahara, K., Sasaki, K. and Noparatnaraporn, N. (2003) Biosorption of Cadmium Ions Using Photosynthetic Bacterium, Rhodobacter sphaeroides S and a Marine Photosynthetic Bacterium, Rhodovulum sp. and Their Biosorption Kinetics. Journal of Bioscience and Bioengineering, 95, 374-378. http://dx.doi.org/10.1016/S1389-1723(03)80070-1

[15] Jasper, P. (1978) Potassium Transport System of Rhodopseudomonas capsulata. Journal of Bacteriology, 133, 13141322.

[16] Sasaki, K. and Takeno, K. (2014) Practical Decontamination of Radioactive Polluted Soil by Photosynthetic Bacteria and Recycle Use for Agriculture. Seibutu-Kougaku, 92, 13-15.

[17] Kobayashi, T. (2012) Suppressive Effects of Radioactive Cesium Incorporation during Vegetable Cultivation by Zeolite Addition, Information of Supporting Technologies Related to Radioactive Pollution. Division of Crop and Gardening, Agricultural Complex Center of Fukushima Prefecture, Japan.

[18] Saitoh, M. (2012) Radioactive Cesium Incorporation of Vegetables Was Suppressed by the Increase of Potassium, Information of Supporting Technologies Related to Radioactive Pollution. Division of Crop and Gardening, Agricultural Complex Center of Fukushima Prefecture, Japan. 